\title{
Multilingualism, language contact and translation in Walter Scott's Scottish novels
}

\author{
Fernando Toda \\ University of Salamanca
}

\begin{abstract}
No one bade us welcome, nor did anyone offer to take our horses [...] and to our various enquiries, the hopeless response of "Ha niel Sassenach" was the only answer we could extract. [Frank Osbaldistone arrives at the clachan of Aberfoil, in the Highlands.] (Rob Roy, ch. 28, 254) ${ }^{1}$

"[...] How far can you walk in a day?"

"Five-and-twenty miles and a bittock."

"And a what?" said the Queen, looking towards the Duke of Argyle.

"And about five miles more," replied the Duke. [Jeanie Deans meets the Queen.] (The Heart of Mid-Lothian, ch. 37, 396)
\end{abstract}

In his Scottish novels, Walter Scott foregrounded the multilingual and multidialectal situation of Scotland. He not only made a deliberate effort to reflect the different linguistic varieties in the dialogues, but also, through his narrators, drew his readers' attention to the variety being used or the pronunciation employed. Since Scott is writing about post-Union Scotland, he implies that the United Kingdom is a multilingual and multicultural society, and that the British have to be aware of this in order to make their union stronger in its diversity, by preserving national cultural identities and values. Evidence is given from three of Scott's most relevant Scottish novels.

\section{The image of a multicultural and multilingual United Kingdom}

The two quotes above are good illustrations of a factor that is constantly present in Walter Scott's Scottish novels: the multilingual setting in which they take place. Writing about Scotland after the Treaty of Union of 1707, Scott was consciously and deliberately depicting a multilingual nation, part of a larger state, the United Kingdom of Great Britain, which had become, consequently, a multicultural and multilingual country. This United Kingdom has as its citizens people who, like some of the Highlanders at the clachan of Aberfoil, 'have no English' and speak only Gaelic, and others who use Lowland Scots, not always understood by speakers of English in England. That is the case of Jeanie Deans, whose expression needs to be 'translated' for the Queen.

In this paper, I shall analyse the way in which Scott makes his readers - his British readers - aware of this multilingual situation and therefore of the cultural and historical differences it represents. The foregrounding of this multilingualism and the situations of language contact derived from it are, in my opinion, very much a part of the ideology underlying the 
Scottish novels. I have previously held (Toda 1991) that Scott's vision of history - especially Anglo-Scottish history - was enhanced through his portrayal of the different languages and dialects used in the novels. My studies in this line actually stemmed from a comment in Román ÁlvarezRodríguez's 1980 PhD dissertation Configuración del héroe colectivo en la novela histórica inglesa (which gave rise to parts of Álvarez-Rodríguez 1983). He suggested that Scott's use of linguistic variety within narrative in Standard English produced a sense of blending and enrichment. It was as if the two varieties in the novels (he only mentioned Scots and English) came together in a way that illustrated the merging of England and Scotland into the United Kingdom. I wished to test this systematically on the basis of the linguistic evidence. My conclusion was that there very definitely was a linguistic side to the historical lesson that Scott wished to present to his British readers. ${ }^{2}$ I was then thinking basically of the function of dialogue in the novels. Terms such as multilingualism and multiculturalism were not much in use then, but my subject obviously has much to do with the idea of "fictionalising language contact and translation", which is why I decided to revise some of that work in the light of the theme of the present volume.

The idea that Scott's representations of linguistic variety are doing the work of consolidating a post-1707 multicultural vision of Great Britain has also been explored in Robert Crawford's Devolving English Literature (1992) and Leith Davis's Acts of Union: Scotland and the Literary Negotiation of the British Nation (1998). This places studies on Scott's use of language as a reflection of cultural and social tensions in a line similar to that pursued in the insightful analyses of Margery Sabin in The Dialect of the Tribe (1987), in which the critic deals with later authors (James, Lawrence, Joyce, Beckett).

Walter Scott has been praised for his 'good ear' in depicting the vernacular of Lowland Scotland, the variety known as Scots. He is probably at his best in writing dialogue when he uses this dialect, but he needs to represent the other languages and varieties used in Scotland as well. I have classified them as follows.

Standard English: this is the language Scott uses for his narrative, and also for the speech of characters that come from England and are fairly educated. Scott also depicts dialects of English in England.

Lowland Scots: this variety has the same origins as Standard English; it is the evolution of Old English (or Anglo-Saxon) in Scotland. For centuries there were two separate Standards in Great Britain: that of London and that of Edinburgh. They were the languages of the courts of the two independent kingdoms that shared the same isle. With the Union of Crowns in 1603 and the Union of Parliaments in 1707, Scots lost its status as an all-purpose variety and became subordinate to Standard English, and Scott was well aware of this. He uses it for the speech of his Lowland characters, but not for narrative.

Highland Scots: this is Scots as spoken by Highlanders whose first language is Gaelic. The interference from that mother tongue is shown in 
traits such as the 'incorrect' pronunciation of certain English consonants, the use of Gaelic words for want of English ones, and mistakes in the use of the personal pronouns and the modal auxiliaries. In portraying it Scott draws on a literary tradition in Scotland, which often employed this variety for comedy. He generally uses it for characters that are to some extent comical, though they sometimes stand for a sort of 'cultural synthesis' between Highlands and Lowlands, as does the Captain of Knockdunder in Waverley.

Gaelic / Ossianic English: Scott knew very little Gaelic. Except for a few odd words, often in 'corrupt Gaelic' (e.g. the "Ha niel Sassenach" expression above) which he throws into the dialogues of native speakers of the language, their speech is rendered in English. (In any case, it would have made things very difficult for his readers if he had made his characters actually speak Gaelic.) He either lets the reader know that the characters are speaking Gaelic by mentioning it specifically, and/or he uses a variety of English which I have termed Ossianic, since it seems to be modelled on the language of Ossian's poetry. ${ }^{3}$ It is a rather high-flown, metaphoric and formulaic language, which, he tells us, is the product of the translation into English, in the speaker's mind, of thought conceived in Gaelic. In short stories such as "The Highland Widow" (1827), Scott uses this type of English as his rendering of what a character actually says in Gaelic.

These four varieties are not always clear-cut, and Scott shows a good perception of the sociolinguistic situation of his country. There are extremes, of course: monolingual speakers. Normally, English characters do not vary in their range of use. They consistently speak Standard English (or a dialect). A few Highland characters only speak Gaelic, and the readers are informed of this fact and their speech is presented as Standard or sometimes Ossianic English (e.g. the case of "The Highland Widow" already referred to above). But there are a number of bilingual characters who use two languages (Gaelic and English or Scots), and some are bidialectal, speaking Scots and Southern (usually Standard) English. They normally vary in a continuum ranging from 'broad Scots' to Standard English. Such is the case of Jeanie Deans in The Heart of Mid-Lothian, for example. We also have characters who speak Gaelic and Highland Scots. Then there are characters that can speak Gaelic and Standard or Ossianic English (such as Fergus and Flora McIvor in Waverley), but do not use Scots, and others who can use all three: Gaelic, Lowland Scots and Standard English. This is, for example, the case of Rob Roy, who resorts to language as a disguise to conceal his true identity.

Scott's representation of this multilingual situation and its sociolinguistic implications is, in my opinion, a major component of his message to his readers. The renderings of the different varieties, or even the changes from one to the other, are perhaps not always sociolinguistically accurate, but Scott's manipulation of them in the interest of his message is masterly. Graham Tulloch (1980) dealt extensively with the way in which Scott carries out the representation of dialect in writing. It must be said, however, that Norman Page, in his major work Speech in the English Novel (1973), had 
already made a brief and mostly accurate description of the process followed by Scott.

\section{Three representative novels}

I have chosen three novels to illustrate Scott's foregrounding of multilingualism. In my opinion, this technique is present in all of the Scottish novels, but it is especially relevant in these.

Waverley (1814) (abbreviated for reference purposes as Wav), Scott's first novel, is placed in the second Jacobite Rising, led by Charles Edward Stuart, "Bonnie Prince Charlie", the Young Pretender, in 1745. Edward Waverley, a young English officer in the British army, travels to Scotland and we are given his impressions of the country and the relations between Scotland and England, including the differences between Highland and Lowland Scotland. The novel already includes all of the varieties mentioned above, and several characters can switch languages or dialects. The young English hero is exposed to the reality of Highland and Lowland Scotland, and is struck by the linguistic differences.

Rob Roy (1817) (abbr. RR). Set in 1715, the time of the first Jacobite Rising, led by James Stuart, the Old Pretender (son of the deposed James II of England and VII of Scotland), after the Union of 1707. The protagonist and first-person narrator is Frank Osbaldistone, a young Englishman who travels into Scotland, both Lowland and Highland. Like Waverley, he learns about the peculiarities of Scottish life and society, and the historical reasons behind some of the situations he meets. Much of this is expressed through the interaction of the different linguistic varieties, to which the narrator often makes reference. One of his masters, both directly and indirectly, is the historical figure of Rob Roy, whom Scott brings into the novel as a multilingual hero.

The Heart of Mid-Lothian (1818) (abbr. HML). Set in 1736, at the time of the Porteous Riots. The people of Edinburgh storm the prison (known as the Heart of Mid-Lothian) and lynch Captain Porteous, who had been sentenced to death for ordering his troops to shoot upon the crowd after a public execution, but had just been granted a reprieve. The tension between London (the Crown and Government) and Scotland (especially the city of Edinburgh) is the background for the story of Jeanie Deans. This devout Presbyterian woman is faced with the moral dilemma of having to lie in court in order to save the life of her sister, accused of infanticide. Unable to do so, she travels to London to obtain the King's pardon for her.

In each of the three novels, the historical background chosen by Scott is a key moment of tension between England and Scotland after the Union, and thus a testing ground for the strength and possibilities of the new United Kingdom. Scott was a defender of the Union because it put an end to many centuries of fighting between the two nations and meant economic progress for Scotland. But he was also very much a nationalist, and wanted to make 
sure that the rights and peculiarities of Scotland should be respected and preserved within the United Kingdom. This includes the two cultures and languages of Scotland, Lowland and Highland. With his depiction of characters from both, identified through their language, he tries to put across a message one might summarise in modern terms as a plea for 'unity in diversity' and for equal justice and respect for the minorities.

\section{The use of linguistic variety in the novels}

I will not endeavour to give a detailed description of the traits Scott uses to depict the different varieties (especially Scots); readers are encouraged to consult Tulloch (1980) for an excellent study of this. It must be said that Tulloch's work is basically descriptive; for the most part, he does not analyse the function of the dialects or varieties in Scott's works. What I wish to focus on here are the indications given by the narrators as to the way in which the characters express themselves. Such comments show that the author wanted his audience to bear in mind the linguistic differences that reflect historical conflict.

In what follows, I will give a few examples from the selected novels to show how Scott draws attention to linguistic variety, apart from reflecting it in the dialogues. I will offer more dialogue quotes from the first novel, Waverley, to give the reader an idea of how Scott represents speech, and in the other works I will concentrate more on the narrator's references to the language or variety used and the situation in which speech is uttered.

\subsection{Waverley}

In his very first novel, Scott decided to deal with a violent episode of Scotland's recent past. The fictional story of Edward Waverley is set against the background of the crushing of the second Jacobite rebellion. We get many indications of the role he intends the spoken language to play in his construction of the novel. For example, on the eve of the battle of Prestonpans, at night, within hearing range of the enemy, Waverley (who had been in the British army before and has ended up in the Young Pretender's army) suddenly becomes conscious of the absurdity of the situation in which he has become involved. The clash of different tongues helps to make him aware of this.

He could hear, too, the well-known word given in the English dialect by the voice of the commanding officer, for whom he had felt so much respect. It was at that instant, that, looking around him, he saw the wild dress and appearance of his Highland associates, heard their whispers in an uncouth and unknown language ... and wished to awake from what seemed at the moment a dream, strange, horrible, and unnatural. (Wav, ch. 46, 353; emphasis added) 
The references to the "uncouth and unknown language" are, of course, to Gaelic, and we are to take them as Waverley's impression. At that moment, he feels completely alien to the cause he is about to fight for, and the strange tongue used by the Highlanders emphasises this. On the other hand, the reference to the English dialect is significant. Scott seems to wish to reflect the idea that both Lowland Scots and Southern English are varieties of one language (call it English), and the use of dialect here places them on an equal footing.

When he enters Scotland, Waverley encounters a multilingual, multidialectal society. A good example of this is the Baron of Bradwardine, a Lowland laird who backs the Jacobite cause. When he is first introduced, we are made to remark on the peculiarities of his language and looks: "He was dressed carelessly, and more like a Frenchman than an Englishman of the period [...] The truth was, that his language and habits were as heterogeneous as his appearance" (Wav, ch. 10, 86-87; emphasis added). Indeed, Scott makes the Baron speak a mixture of Standard English and Scots, which can range closer to one or the other end, and has him use lots of legal Latin and some French expressions too. This makes his language comical, and we are told that some of his interlocutors laugh at his speeches, yet there is a message: his language reflects the historical circumstances that he has lived in.

When Waverley visits Tully-Veolan, the Baron's estate, a typical Highland event takes place: a cattle raid. The baron's cattle are driven off by Fergus McIvor, a Highland chieftain, who also supports the Jacobite cause but wants to blackmail him. Waverley comes into contact with his men, one of whom is Evan Dhu McCombich, a Highlander, and Fergus's lieutenant. He speaks English to Waverley, and sometimes explains differences: "See, there is an earn, which you Southrons call an eagle - you have no such birds as that in England" (Wav, ch. 16, 135; emphasis added). He includes Scots words in the English he speaks to Waverley, who sometimes does not understand. Thus, the narrator lets us 'hear' Evan talking about the daughter of a Highland cateran, "who, he said, was both canny and fendy; and was, to the boot of all that, the best dancer of a strathspey in the whole strath. Edward assented to her praises so far as he understood them" (Wav, ch. 18, 148; emphasis added). My belief is that when Scott does things like this, he is spurring his English readers. It is a way of saying: "Can you understand this? This is the way some people speak in our country".

Sometimes, Evan acts as a translator (an interpreter, to be more precise) for Waverley, explaining terms. A case in point is the Gaelic name Sidier Dhu, which he explains. "The black soldier; that is what they call the independent companies that were raised to keep peace and law in the Highlands [...] They call them Sidier Dhu, because they wear the tartans - as they call your men, King George's men, Sidier Roy, or red soldiers" (Wav, ch. 18, 150).

Evan plays a heroic role in the novel. As opposed to his master, Fergus McIvor, who no longer stands for what Scott seems to consider the tradi- 
tional Highland virtues of loyalty, honour and bravery, Evan does embody these. When both men are tried by a British court in Carlisle, charged with treason for backing the Jacobites, Fergus makes a rather elaborate, literary speech in Ossianic English. But Evan, at first, finds it hard to utter anything. We are told that he "seemed anxious to speak; but the confusion of the court, and the perplexity arising from thinking in a language different from that in which he was to express himself, kept him silent" (Wav, ch. 68, 465; emphasis added). A native speaker of Gaelic, Evan is going to have to use a second language for his statement. When he does speak out, his speech is in Lowland Scots. Though this might be sociolinguistically 'inaccurate', Scott's choice is, for his purposes, the best. He could have had Evan use Highland Scots, but, as Tulloch (1980: 32) suggests, the dialect had too many comical connotations from earlier literature, making it risky to use it in a key passage like this. He could have used Ossianic English, which he in fact employs when he first addresses the Baron of Bradwardine, but that is the variety used by his chief, Fergus, who is less convincing because he is more alienated from the true Highland values. By giving him Lowland Scots in this passage, Scott makes Evan represent 'North Britain', using a variety different from that of the south, and at the same time he makes us aware of the Highland values that should, ideally, contribute to a better United Kingdom.

Other characters in the novel speak Highland Scots, and resort to many Scots or Gaelic words, making it hard for Waverley to understand them. In chapter 16, Digald Mahony, a Highlander, one of Fergus McIvor's men, is charged with accompanying him to meet Donald Bean Lean, a cateran, who may be able to help him. On their journey, Waverley enquires of Digald whether they still have a long way to go, and this is the answer, presented to the reader as 'quoted indirect speech', a device often used by Scott: "Ta cove was tree-four mile; but as Duinhé-wassel was a wee taiglit, Donald could, tat is might - would - should send ta curragh" (Wav, ch. 16, 137). The narrator's comment is: "This conveyed no information. The curragh might be a man, a horse, a cart, or a chaise" (Wav chapter 16, 138) - curragh turns out to be a boat. Here we have Highland Scots. 'Th-' comes out as ' $t$ '; there is hesitation in the use of the modal auxiliaries; Gaelic words are used in conjunction with Lowland Scots vocabulary.

When Waverley arrives at Donald's hideaway, he meets his daughter Alice, a monolingual Gaelic speaker. We are told about "the laughing eyes with which, in dumb show, she gave Waverley that morning greeting which she wanted English words to express" (Wav, ch. 18, 146; emphasis added). However, later on, when Waverley returns to Tully-Veolan, he learns that one of the novelties is that Alice and Rose Bradwardine (the Baron's daughter, a Lowlander) have become friends. We are informed that "Alice, who could now speak a little English, was very communicative" (Wav, ch. 65, 447; emphasis added). Here is a good case of language contact. Alice, hitherto isolated in an all-Gaelic environment, has now begun to learn a second language. What does it sound like? We 'hear' it when she resolves to give back some documents to Waverley without her father's knowledge, since " 'they 
may oblige the bonnie young lady [Rose] and the handsome young gentleman [Waverley],' said Alice, 'and what use has my father for a wheen bits o' scarted paper?'" (Wav, ch. 65, 447). She has learned to speak Lowland Scots. This makes sense: in the Highlands, among her father's followers, she would only hear (and need) Gaelic. This single instance of the Scots she has learned in the Lowlands shows no traces of Gaelic vocabulary or traits of Highland Scots pronunciation or 'grammar'. If Scott had wanted these to appear, he would certainly have included some in what is her only speech in the novel. Notice also that Alice's speech is labelled as "English", though it is not Standard English, but Lowland Scots. The important thing here is the opposition between Highland (Gaelic) and Lowland language, the second being encompassed by "English" as a cover-term (which would include also the "English dialect" mentioned above).

Language is sometimes a means of deception. At one point, Waverley is surprised by one of Rose Bradwardine's servants, Janet Gellatley, when she addresses him: “'God bless you! God prosper you, Captain Waverley!' said Janet, in good Lowland Scotch, though he had never hitherto heard her utter a syllable save in Gaelic" (Wav, ch. 37, 279; emphasis added). At that moment, he cannot get more information from her, but towards the end of the novel he finds out that she was under orders from Rose: "she gar'd me speak aye Gaelic when ye was in hearing, to mak ye trow ye were in the Hielands. I can speak it weil eneugh, for my mother was a Hieland woman" (Wav, ch. $65,445)$. Here, then, is another case of bilingualism, a Lowland child brought up by a Highland mother. And this may be useful for purposes of deception.

Flora and Fergus McIvor, leading Highlanders, speak English to Waverley, though they are native speakers of Gaelic. This case is similar to that of Helen McGregor in Rob Roy, so I will not deal with it here, and move on to that novel.

\section{2. $R o b$ Roy}

This is probably one of the richest novels in comments about language, most of them caused by the figure of Rob Roy. Because it also applies to Fergus and Flora in Waverley, I shall begin by referring to Scott's idea of "Gaelic mentally translated into English", mentioned above in the case of Evan Dhu. Here the English first-person narrator, Frank Osbaldistone, explains the theory. When he and Bailie Nicol Jarvie (a Lowlander, from Glasgow) fall prisoners to the McGregor clansmen, the bailie makes a plea for mercy to Helen McGregor, claiming that he is related to their chief and her husband, Rob Roy. She rejects that relationship "by demanding haughtily, 'If a stream of rushing water acknowledged any relation with the portion withdrawn from it for the mean domestic uses of those who dwelt on its banks?' " $(R R$, ch. 31, 291). Note again that Scott resorts to 'quoted indirect speech', and that Helen speaks a rather elaborate variety of Standard English. After Helen's 
speech, in which she finally acknowledges the relation to Jarvie, Frank makes the following comments:

\begin{abstract}
All this was said with the manners of a princess, and in the tone and style of a court. Nor was there the least tincture of that vulgarity, which we naturally attach to the Lowland Scottish. There was a strong provincial accentuation, but, otherwise, the language rendered by Helen McGregor, out of the native and poetical Gaelic, into English, which she had acquired as we do learned tongues, but had probably never heard applied to the mean purposes of ordinary life, was graceful, flowing, and declamatory. (RR, ch. 35, 343; emphasis added)
\end{abstract}

Scott makes the narrator, an Englishman, admit that "we" - the English usually consider Lowland Scots "vulgar". Note also the observation that Helen has learned her English from books, like one learns Latin. Finally, and most importantly, there is his idea that these non-native speakers of English must go through a mental process of translation, which makes the underlying structure of their 'poetic' mother tongue come through to the surface structure of their second language. The result is what I have earlier termed Ossianic English. ${ }^{4}$

Before that scene, one of Rob Roy's men, Dougald Gregor, speaks on behalf of the prisoners: "[I]n his own language, which he spoke with a fluency and rapidity strongly contrasted by the slow, imperfect, idiot-like manner in which he expressed himself in English, [he] poured forth what I doubt not was a very animated pleading on our behalf' $(R R$, ch. 31 , 292-293). Scott, through Frank, wishes to remind his readers that when Highland characters speak English (or Scots) these citizens of the United Kingdom sound 'funny' because they are not communicating in their native language.

Rob Roy uses the whole linguistic range displayed in Scott's novels (except Highland Scots, which he does not need). Frank Osbaldistone's comments are especially revealing. From the very beginning, when he remarks on how Rob's "Scottish accent" struck his English ears $(R R$, ch. 4,32$)$ to his final recognition of "a voice I knew right well" in the ambush in which Rashleigh is killed by Rob $(R R$, ch. 39,379$)$, we find a considerable number of observations related to the different languages Rob speaks, or his changes in register or dialect, often related to his emotional state. Thus the first time Rob appears as "Mr. Campbell" at an inn in Darlington (England), Frank detects in his speech "the national intonation and slow pedantic mode of expression arising from a desire to avoid peculiarities of idiom or dialect" (RR, ch. 4, 35). Rob, under a false name, also disguises his speech, approximating Standard English. We get many instances of such changes in the novel, and the 'theory' behind this is actually set out by Frank in a passage that comes immediately after his explanation of Helen's English as a translation of Gaelic (see above):

Her husband, who had in his time played many parts, used a much less elevated and emphatic dialect, - but even his language rose in purity of expres- 
sion, as you may have remarked, if I have been accurate in recording it, when the affairs he discussed were of an agitating and important nature; and it appears to me in his case, and in that of some other Highlanders whom I have known, that, when familiar and facetious, they used the Lowland Scottish dialect, - when serious and impassioned, their thoughts arranged themselves in the idiom of their native language; and in the latter case, as they uttered the corresponding ideas in English, the expressions sounded wild, elevated, and poetical. (RR, 35, 343-344; emphasis added)

Frank, writing his memoirs to an English friend "in the decline of my life" ( $R R$, ch. 1, 5) seems to have rendered speech quite accurately, in fact. Once again, there seems to be a conscious effort on Scott's part to make readers aware of linguistic variety.

The pattern set out above for Highland speakers is, however, not followed very consistently in the case of Rob Roy, who actually uses Lowland Scots (not Ossianic English) to talk about an affair "of an agitating and important nature": the execution by his men - without his knowledge - of an English excise man (chapter 34). But this use is more effective. As in the case of Evan, Scott cannot make Rob use Highland Scots because of the comic connotations, and he cannot give him Ossianic English, because it has to contrast with his wife's language. Rob is a man who has lived in many parts of the country due to historical circumstances. British law does not allow him to wear the Highland dress or to use his Highland name. In this sense, it is relevant that before he makes his speech about the Englishman's death, he clearly identifies himself as a Highlander, when he asks Frank, who calls him "Mr Campbell", to tell him how the gauger came to be killed: "How fell that, sir? - Speak out, sir, and do not Maister or Campbell me - my foot is on my native heath, and my name is McGregor!" (RR, ch. 34, 323). Even if he uses Lowland Scots, he is identified as belonging to the Celtic culture of Scotland.

Through the words of his cousin, Nicol Jarvie, Scott tells us the story of Rob Roy, and we learn how historical circumstances led him to change from a peaceful cattle drover to an outlaw in the eyes of the British government. In fact, Scott puts this in Rob's own words when he talks about "what I have been - what I have been forced to become - and above all, that which has forced me to become what I am" ( $R R$, ch. 35, 334). His use of two languages, including at least two varieties of one of them (Scots and Standard English), is a reflection of those historical circumstances. 5

In Rob Roy, Lowland speech is best exemplified by Nicol Jarvie, the bailie, and Andrew Fairservice, whom Frank takes on as his servant or aide. There is a political difference between them, however. Andrew is a fervent anti-unionist, while Jarvie has come to see the benefits of the Union. This is the way in which he upbraids Andrew for his criticism of it:

It's ill-scraped tongues like yours, that make mischief atween neighbourhoods and nations. There's been naething sae gude this side o' time but it might hae been better and that might be said o' the Union. Nane were keener against it than the Glasgow folk [...] Now, since St. Mungo catched herrings in the Clyde, what was ever like to gar us flourish like the sugar and 
tobacco-trade? Will ony body tell me that, and grumble at the treaty that opened us a road west-awa' yonder? $(R R$, ch. 27,246$)$

Both Lowland characters speak Scots, and Jarvie's defence of the Union in that variety is significant. Both are good and loyal men, though the implications are that Fairservice's beliefs are probably outdated. Yet he too deserves respect for his ideas, and his moral values are sound and should not be disregarded.

Oral translation (i.e. interpreting) comes into the novel too, at times rather humorously. Rob Roy, having escaped from the government troops, reunites with his men and Frank Osbaldistone. His followers ask him to repeat the story of his escape, which he obviously tells in Gaelic, "at least a dozen times over, as I was told by an officious old man, who chose to translate it at least as often for my edification, and to whom I was in policy obliged to seem to pay a decent degree of attention" (RR, ch. 34, 327).

\subsection{The Heart of Mid-Lothian}

The novel is set mostly in the Lowlands and England, and it is Lowland Scots that is most relevant here. The protagonist is Jeanie Deans, for our purpose the most interesting speaker in this novel, and Scott's only Scotsspeaking heroine. With her (and her sister Effie) Scott makes a special effort to give back to the Scots dialect part of the all-purpose character it had enjoyed earlier in Scottish literature. After the historical blows it had received (Union of Crowns in 1603, Union of Parliaments in 1707), Scots had lost its status in the face of Standard English. In fact, David Murison (1978: 5) claims that the first blow had been the absence of a translation of the Bible into the Scots vernacular, which meant that, with the Reformation, Southern English became the language of Scripture for Scotland. Here Scott wants to restore it, at least in part, to its former role. Consequently he uses Scots, for example, in one of the key moments of the novel, the dialogue between Jeanie and her sister Effie in prison (chapter 20). Both use the dialect, and it is marked as fairly broad Scots, the variety they would normally talk to each other. In this dramatic moment, Scots is the vehicle for tragedy.

Jeanie can, in fact, switch to Standard English. In chapter 29, she uses it to address the highwaymen who try to rob her, and in chapter 32 , her English contrasts with the Lincolnshire dialect of the beadle of an English parish. At a key point in the novel, when she is about to meet the Queen, in order to plead for her sister's life, Scott ensures that we never forget that she is speaking in her dialect, even when the frequency of dialect indicators in her speech (spelling, vocabulary, syntax) is lower. This is carefully brought about. When she first meets the Duke of Argyle, a Scottish Member of the British Parliament who is to organise her interview with the Queen, she tries to explain her story in English. The Duke interrupts her: "just speak out a 
plain tale, and show you have a Scotch tongue in your head" (HML, ch. 35, 374; emphasis added). Jeanie then tells him of her sister's plight in Scots. When they are about to meet the Queen, he again advises her: "Just speak as plainly and boldly to his lady, as you did the day before yesterday" (HML, ch. 36, 384). The implication is that she is to speak Scots. When she first begins to speak, we learn that the Queen smiled "at the first sound of her broad northern accent" (HML, ch. 37, 394). There are a number of Scotticisms in her speech, and the Queen does not understand some and requires 'translation', as in the quote heading this paper. In a moment of historical tension between England and Scotland, Jeanie's use of Scots reminds us that she is a Scottish subject of the Queen she is addressing. ${ }^{6}$

\section{Scott's fictionalisation of language contact: a historical lesson for British readers}

In my opinion, the instances quoted above (just a few samples of many more to be found in these three and in the other Scottish novels) prove that Scott had a definite political and didactic purpose in portraying linguistic variety. He wanted his British readers to understand the underlying historical tensions between England and Scotland, and between Highlands and Lowlands, not only through the historical background to the stories told, but also through the interaction of the language varieties used by his fictional (and sometimes historical) characters. He goes out of his way to foreground this through his narrators, and seems to be urging his readers to accept 'the others' as they are - including their language. In some cases, his narrator's comments show the prejudices that he was aware of, and which he knew many of his English readers would share. Such is the case of the narrator's comment (which to me is very close to free indirect speech, and therefore attributable to the character, not the narrator) when Edward Waverley hears the Highlander's words whispered "in an uncouth and unknown language". In Rob Roy, the same applies to Osbaldistone's comments about Helen Mc Gregor when he says that in her English there was not "the least tincture of that vulgarity, which we naturally attach to the Lowland Scottish", or to those he makes on the Highlanders at Aberfoil. (In fact, some of the children who claim that they "Ha niel Sassenach" end up speaking English when they are offered money.) The linguistic differences often relate to differences in wealth or social position, and contribute to the feeling that much social and political restructuring needs to be done in this new multicultural nation.

I am aware that Scott's political position was certainly not that of a radical social reformer. However, I tend to agree with Marilyn Butler (1981: 110) when she holds that "Scott's underlying didactic aim is clearly the cause of social harmony", as well as with critics such as Lukács (whose essay on Scott was the first chapter of his seminal work The Historical Novel in 1937) and Álvarez-Rodríguez (1983), who claim that the people, as a sort of 'collective hero', are the key protagonists of many of Scott's novels. This 
is also the case in his 'period' novels (e.g. Ivanhoe), but in the Scottish novels the impression is further grounded in his use of linguistic variety. I believe that some sociolinguistic prejudices sometimes seem to show through Scott's narrative. In Jeanie's major scene, as we have seen, he tells us that the Queen smiled at her "broad northern accent". But immediately he adds that when Jeanie started to plead her case she did so "in tones so affecting that, like the notes of some of her native songs, provincial vulgarity was lost in pathos" (HML, ch. 37, 394). Are we to take this as Scott's point of view as a narrator? To me this case is not the same as that of the comments made by the narrator in Rob Roy, and does not come as close to 'free indirect speech' as the comment on the language heard by Edward Waverley for us to take it as the Queen's opinion. Scott was probably well aware that to many of his English readers the Scots dialect would sound "vulgar", and that the connotations went beyond a lack of euphony and entered the realms of history and politics. Here he may be making a concession. The fact that he refers to her "broad northern accent", not labelling it as "Lowland Scottish", is not irrelevant, to my mind. He is playing on the idea of "northern Britain" because he wants to emphasise that this is now one country, though made up of different nations, and with different languages or varieties. The interaction between these varieties is a reflection of the historical tension that has gone into the making of Great Britain, and that tension, and the social and economic differences involved, are by no means gone. Scott has a definite didactic purpose in writing for the British about the history of Scotland, and his fictionalising of language contact and translation is a key element in his work. $^{7}$

I believe there is more than enough linguistic evidence in Scott's fictional writings to justify such a conclusion. As to his position on the situation of Scotland within the Union, I would like to quote three significant non-fictional passages. At the beginning of Tales of a Grandfather, the history book that Scott wrote for his grandson (and for all the British children he hoped would read it) in 1828, he included these lines:

Now, as these two nations [England and Scotland] live in different ends of the same island, and are separated by large and stormy seas from all other parts of the world, it seems natural that they should have been friendly to each other, and that they should have lived as one people under the same government. (TG, 5-6)

However, two years earlier, in The Letters of Malachi Malagrowther (1826), Scott had protested strongly against the way in which the British government was ignoring the terms of the Treaty of Union in trying to pass a bill about the currency, which he felt would affect Scotland very negatively, without listening to the opinion of the Scots representatives. Referring to this situation, he wrote:

For more than one half of last century, this was a practice not to be thought of. Scotland was during that period disaffected, in bad humour, armed, too, 
and smarting under various irritating recollections. [...] This period passed away, a happier one arrived, and Scotland, no longer the object of terror, or at least great uneasiness, to the British Government, was left from the year 1750 under the guardianship of her own institutions, to win her silent way to national wealth and consequence. (LMM, 9)

A few pages later, he claims that the Government tended to be much more wary of acting in a similar way in relation to Ireland (which had become part of the United Kingdom in 1801) because of the threat of violence:

This gratification of his humour is gained by Pat's [i.e. the Irish] being up with the pike and shilelah on any and no occasion. God forbid Scotland should ever retrograde towards such a state [...] We had better remain in union with England, even at the risk of becoming a subordinate species of Northumberland, as far as national consequence is concerned, than remedy ourselves by even hinting the possibility of rupture. But there is no harm in wishing Scotland to have just so much ill nature [...] as may keep her goodnature from being abused; so much national feeling as may determine her to stand by her own rights, conducting her assertion of them with every feeling of respect and amity towards England. (LMM, 17-18)

Scott openly rejected violence, but demanded quite adamantly (and with excellent arguments) that Scotland's rights be respected. The Letters were so successful that the British Government withdrew the bill in question. I believe the explicit message contained in these two passages is very much the implicit message in the Scottish novels: the Treaty of Union is a positive step in history, but respect for national differences and rights is essential if it is to be a fair basis for coexistence. In the Scottish novels, the multilingual, multicultural aspects of the United Kingdom are to a very large extent represented by the fictionalisation of language contact through the use of dialogue and narrative commentary. As one of the creators, if not the absolute 'father' of modern historical fiction, Scott would seem to be the obvious starting point for studies regarding genre and the specificity of certain literary representations of language and translation. In this case the genre is historical fiction. Georg Lukács held that

The historical novel [...] has to demonstrate from artistic means that historical circumstances existed in precisely such and such a way. What in Scott has been very superficially called "authenticity of local colour" is in actual fact this artistic demonstration of historical reality. (Lukács 1969: 108)

Lukács did not make specific reference to the use of language in the novels, but it is obvious that "authenticity of local colour" is to a great extent afforded by the dialogue. This "authenticity" is what Maria Edgeworth had achieved with the use of Irish English (or Hiberno-English) in works like Castle Rackrent (1800). Scott took Edgeworth as his model for the incorporation of dialect into the novel, as he avowed in the preface to the 1829 edition of the Waverley Novels. However, his purpose in representing linguistic variety went much further than hers, and Rackrent was not what we call a 
historical novel. Scott, as the initiator of a genre, may then be said to have incorporated linguistic variety into it for his "artistic demonstration of historical reality". To what extent did he set a model, in this language-related aspect, for the development of the genre, not only in Britain but also in Europe and America? The question goes far beyond what I set out to demonstrate in this paper, but it seems fairly obvious that the answer requires starting with a clear vision of what Sir Walter Scott intended to do with his representation of multilingualism, language contact and translation in historical fiction.

\section{Bibliography}

\section{Primary sources (and abbreviations)}

Scott, Walter (1972 [1814]). Waverley. Harmondsworth: Penguin Books. (abbr. Wav) Scott, Walter (1978 [1817]). Rob Roy. London: J.M. Dent \& Sons. (abbr. RR)

Scott, Walter (1971 [1818]). The Heart of Mid-Lothian. London: J.M. Dent \& Sons. (abbr. $H M L)$

Scott, Walter (1981 [1826]). The Letters of Malachi Malagrowther. Edinburgh: William Blackwood. (abbr. LMM)

Scott, Walter (1926 [1827-1830]). Tales of a Grandfather. Cambridge: Cambridge UP. (abbr. $T G)$

\section{Secondary sources}

Álvarez-Rodríguez, Román (1983). Origen y evolución de la novela histórica ingle$s a$. Salamanca: Ediciones Universidad de Salamanca.

Butler, Marilyn (1981). Romantics, Rebels and Reactionaries: English Literature in its Background 1760-1830. Oxford: Oxford UP.

Crawford, Robert (1992). Devolving English Literature. Oxford: Clarendon Press.

Davis, Leith (1998). Acts of Union: Scotland and the Literary Negotiation of the British Nation. Stanford, California: Stanford UP.

Lukács, Georg (1969 [1937]). "Scott and the Classical Form of the Historical Novel" (tr. H. \& S. Mitchell). A. N. Jeffares (ed.). Scott's Mind and Art. Edinburgh: Oliver \& Boyd, 93-131.

Murison, David (1978). The Guid Scots Tongue. Edinburgh: William Blackwood \& Sons.

Murison, David (1969). "The Two Languages in Scott". A. N. Jeffares (ed.). Scott's Mind and Art. Edinburgh: Oliver \& Boyd, 206-229.

Page, Norman (1973). Speech in the English Novel. London: Longman.

Sabin, Margery (1987). The Dialect of the Tribe. New York: Oxford UP.

Sorensen, Janet (1999). “'Strange Orthography and Singular Diction': Scott's Use of Scots in The Heart of Midlothian". Ton Hoenselaars \& Marius Buning (eds). English Literature and the Other Languages. Amsterdam/Atlanta, GA: Rodopi, 63-74.

Toda, Fernando (1983a). El escocés en la novelística de Walter Scott: función de las variedades lingüísticas en las novelas escocesas. $\mathrm{PhD}$ thesis. University of Seville. 
Toda, Fernando (1983b). "A Scots-Speaking Heroine: Jeanie Deans Meets the Queen in Walter Scott's The Heart of Mid-Lothian". P. Shaw (ed.). Héroe y antihéroe en la literatura inglesa. Madrid: Alhambra, 348-360.

Toda, Fernando (1985). "Archaisms and Scotticisms: Language and Historical Point of View in Rob Roy". Anglo-American Studies 5 (1), 23-33.

Toda, Fernando (1991). "Walter Scott y las lenguas de Escocia". Walter Scott, $L a$ viuda montañesa / Los dos arreadores (translation, introduction and notes by Fernando Toda, foreword by Angus McIntosh). Sevilla: Secretariado de Publicaciones de la Universidad de Sevilla, 9-53.

Tulloch, Graham (1980). The Language of Walter Scott: A Study of His Scottish and Period Language. London: André Deutsch.

${ }^{1}$ See the bibliography for the editions used. For the sake of easy reference chapter numbers are added where appropriate.

2 "La lección histórica que Scott sin duda quiso dar a los británicos tiene un aspecto linguístico" (Toda 1991: 40). This I wrote in the Introduction to my translation of The Highland Widow and The Two Drovers, which drew on material from my PhD dissertation (Toda 1983a), some aspects of which had appeared in Toda (1983b, 1985). I was working on the hypothesis that Scott's historical and political point of view is often reflected in his use of linguistic variety in dialogue.

3 James MacPherson (1736-1796) claimed to have found manuscripts of ancient epic poetry by "Ossian, the son of Fingal" and translated them from Gaelic. In fact he himself had written the book (publ. 1762) in English, in a style which he apparently thought "sounded Gaelic". Tulloch (1980: 320) says that in Waverley Evan Dhu, a native Gaelic speaker, speaks "an English enlivened with Ossianic imagery" when he addresses the Baron of Bradwardine as Fergus McIvor's "ambassador". Observations like these made me opt for the term Ossianic English.

${ }^{4}$ The passage provides a good definition of Ossianic English in Scott's own words. Helen is presented as a Gaelic speaker with a "book knowledge" of English due to her upbringing. The contrast with her husband, who can use more varieties, might provide interesting material for gender studies related to dialogue in fiction.

${ }_{5}$ Rob speaks Gaelic to his clansmen, English when he is passing as Mr Campbell, and Scots. See Toda (1985).

6 Jeanie's use of English rather than Scots forms in some parts of her plea is justified by references to biblical language; "[this Bible English] is the second language of Scotland [...] with which every Scottish peasant was familiar and which he could reproduce in varying degrees of accuracy" (Murison 1969: 224). See also Toda (1983b). In her article "'Strange Orthography and Singular Diction': Scott's use of Scots in The Heart of Midlothian" (1999), Janet Sorensen makes a relevant contribution to the study of Scots in this novel.

7 As a translator of Scott (see Toda 1991) I would add that this is also one of the things that make translating him so frustrating at times: a lot of the linguistic tension is inevitably lost. 